\title{
A high-resolution environmental change record since 19 cal ka BP in Pumoyum Co, southern Tibet
}

\author{
LÜ XinMiao $^{1}$, ZHU LiPing $^{1 *}$, NISHIMURA Mitsugu ${ }^{2}$, MORITA Yoshimune $^{3}$, \\ WATANABE Takahiro ${ }^{4}$, NAKAMURA Toshio ${ }^{5}$ \& WANG Yong ${ }^{1,6}$ \\ ${ }^{1}$ Key Laboratory of Tibetan Environment Changes and Land Surface Processes, Institute of Tibetan Plateau Research, Chinese Academy of \\ Sciences, Beijing 100085, China; \\ ${ }^{2}$ School of Marine Scinece and Technology, Tokai University, Shizuoka 424-8610, Japan; \\ ${ }^{3}$ Botanical Garden, Okayama University of Science, Okayama 700-0005, Japan; \\ ${ }^{4}$ Graduate School of Science, Tohoku University, Sendai 980-8578, Japan; \\ ${ }^{5}$ Centre for Chronological Research, Nagoya University, Nagoya 464-8602, Japan; \\ ${ }^{6}$ Graduate University of Chinese Academy of Sciences, Beijing 100049, China
}

Received May 5, 2011; accepted July 4, 2011

\begin{abstract}
A 380-cm-long sediment core was acquired from the deep water area of Pumoyum Co, southern Tibet. Twenty-five plant residue samples were selected, and organic carbon stable isotopes were obtained using the AMS ${ }^{14} \mathrm{C}$ chronological method. The ${ }^{14} \mathrm{C}$ age and carbon reservoir effect were calibrated with surface sedimentation rate measurements using ${ }^{210} \mathrm{~Pb}$ dating. Results showed that the core sediment deposited over $19 \mathrm{cal}$ ka BP. Based on a multi-proxy analysis of TOC and IC contents, grain size and pollen assemblage data, the palaeoclimatic evolution of Pumoyum Co was reconstructed since the last glacial. Pumoyum Co was a shallow lake prior to $16.2 \mathrm{cal} \mathrm{ka} \mathrm{BP}$; although the glacier around the lake began to melt due to increasing temperatures, climate was still cold and dry. In the interval of 16.2-11.8 cal ka BP, the sedimentary environment fluctuated drastically and frequently. Two cold-events occurred at 14.2 and $11.8 \mathrm{cal} \mathrm{ka} \mathrm{BP}$, and these may correspond to the Older Dryas and the Younger Dryas events, respectively. After $11.8 \mathrm{cal} \mathrm{ka}$ BP, Pumoyun Co developed into the deep lake as it is now. The lake water temperature was relatively lower at that time because of influx of cold water from glacial meltwater entering the lake. As a result, the multi-proxy indicators showed no sign of warm conditions. Comparisons between the sedimentary record of Pumoyum Co with that of other lakes of the same age in southern Tibet indicate a warmer climate following the last deglaciation influenced the southeastern Tibetan Plateau. These results imply that the southwest Asian monsoon gradually became stronger since the deglaciation during its expansion to the inner plateau. The glacial-supplied water of the lake responded sensitively to cold-events. The entire southern Tibet region was dominantly influenced climatically by the southwest Asian monsoon during the Holocene.
\end{abstract}

Tibet, Pumoyum Co, lake sedimentation, environmental change, high resolution, glacial meltwater

Citation: $\quad$ Lü X M, Zhu L P, Nishimura M, et al. A high-resolution environmental change record since 19 cal ka BP in Pumoyum Co, southern Tibet. Chinese Sci Bull, 2011, 56: 2931-2940, doi: 10.1007/s11434-011-4656-Z

Understanding regional climate dynamics is one of the key overarching problems of past global change research. This research seeks to achieve a better comprehension of past regional climate and its variability, in particular over the time scales of the last glacial, the Holocene and the last $2 \mathrm{ka}$ [1]. The hydrological and ecological responses to climate

*Corresponding author (email: lpzhu@itpcas.ac.cn) change influence major land surface processes [2]. Although environmental research over the past $20 \mathrm{ka}$ has been conducted in many regions, there is little published information of well-dated and high-resolution records in the middle and low latitudes [3]. The southern Tibetan Plateau has hydrologically closed inland lakes, which are located in mid-low latitudes. Various environmental proxies, mirroring lake and climate changes, are preserved in lake 
sediments and lake basins. These proxies can be used to investigate climate change over different time scales, hydrothermal conditions, and palaeoecological settings.

As a result of the blocking effect of the Himalayas and the truncation effect of the Yarlung Zangbo River, the southwest (Indian) monsoon strongly influences the southern Tibetan Plateau and the resulting climate types are quite different [4]. Thus, spatial differentiation of climatic records in this region is possible. To date, lake sediment records have obtained only limited coverage in the southern Tibetan Plateau region [5-10]. In addition, there is a lack of highresolution records that encompass the deglacial stage [11-13]. Thus, more long time scale palaeoclimatic studies are needed. In this study, a multi-proxy analysis of TOC, grain size and pollen was used to reconstruct the environmental evolution of Pumoyum Co since 19 cal ka BP. This research is important to generate a better understanding of the regional response to climatic instability since the last glacial.

Pumoyum Co $\left(28^{\circ} 30^{\prime}-28^{\circ} 38^{\prime} \mathrm{N}, 90^{\circ} 13^{\prime}-90^{\circ} 33^{\prime} \mathrm{E}, 5030 \mathrm{~m}\right.$ a.s.l.) is located in the inter-montane basin of the northern slope of the Himalayas. The lake itself covers an area of $290 \mathrm{~km}^{2}$ within the lake basin (area of $1232.9 \mathrm{~km}^{2}$ ). The lake recharge coefficient and the shoreline development index are 4.2 and 1.56, respectively [14]. The mountains around the lake are mainly composed of hypometamorphic rocks of Cretaceous and Triassic age [15]. Quaternary loosed deposits are widespread from the piedmont belt to the lake shore [16]. The lake is situated in the rain-shadow of the Himalayas. According to data during 1976-1994 from the Dui hydrological station on the northeastern shore of the lake, the mean annual precipitation was $357 \mathrm{~mm}$. About $90 \%$ of the rain precipitated from June to September, and mean annual evaporation of the lake surface reached $1770 \mathrm{~mm}$ [17]. Because of the great difference between precipitation and evaporation, surface runoff may be an important factor to maintain the lake water balance. Four major rivers discharge into the lake. Among them, Jiaqu River on the southwestern shore is the largest. Our investigation of river discharge in September of 2004 (Late ice melt) and August of 2005 (Mid ice melt) demonstrates that the influx of Jiaqu River dominated river flow into the lake by $79 \%$ and $77 \%$, respectively, at measuring season [18]. Because modern glaciers and various sizes of glacial lakes are found in the source region of Jiaqu River, and the river has higher fluxes during the glacial melting season, the glacial meltwater is major water supply for Jiaqu River and also for surface runoff supply of the lake. The majority of the surrounding vegetation is alpine meadow-steppe. During the vascular plant survey of the Sino-Japan joint expedition in August, 2006, three main vegetation types were found around the lakeshore [19]: (1) swamp meadows (5020-5021 $\mathrm{m}$ a.s.l.) dominated by plant species of Carex, Potentilla, Polygonum, and Eleocharis, and mostly distributed along the lakeshore and the banks of rivers that flow into the lake;
(2) alpine steppes (5021-5128 m a.s.l.), which are widespread on the gentle slopes along the lakeshore, hosting Androsace, Arenaria, Astragalus, Cyperaceae, Compositae, and Gramineae; and (3) alpine meadows (5128-5193 m a.s.l.), which are located on the eastern and western lakeshore, at the foot of rocky mountain areas, with dominant herbs of Carex, Eleocharis, Kobresia, Poa, Androsace, and Arenaria.

\section{Materials and methods}

\subsection{Sampling}

In the summers of 2004, 2005 and 2006, a HD-27 Single Frequency Echo Sounder and HD8500 Beacon GPS Receiver (Hi-Target Survey Instrument Co. Ltd, China) were used to survey the underwater topography of Pumoyum Co. The depocenter was found to be in the central and eastern part of the lake, where the water depth was $60-65 \mathrm{~m}$. In August 2006, two piston cores (PL06-1and PY608W) with length of $370 \mathrm{~cm}$ and $368.5 \mathrm{~cm}$, respectively, were deployed at the same site, at a water depth of $51.5 \mathrm{~m}\left(28.55158^{\circ} \mathrm{N}\right.$, $90.42843^{\circ} \mathrm{E}$; Figure 1). This work was conducted under the cooperation of the Institute of Tibetan Plateau, Chinese Academy of Sciences (ITPCAS) and Tokai University, Japan. The original drill cores were preserved in PC plastic coring tubes, and then sampled in the laboratory at $1 \mathrm{~cm}$ intervals. Plant residues were found in the lower part of Core PL06-1 and PY608W at $280 \mathrm{~cm}$ and $281.2 \mathrm{~cm}$, respectively (Figure 2). These plant residues extended to the bottom of the two cores [20]. The plant residue-rich layers in both cores were characterized by coarse grain sizes $(>63$ $\mu \mathrm{m})$ with scattered interlayers of $<63 \mu \mathrm{m}$ grain size. The upper layers above the plant residues of the two cores were composed of fine grain sizes $(<63 \mu \mathrm{m})$.

\subsection{Dating}

The ${ }^{14} \mathrm{C}$ samples were prepared with an Acid-Alkali-Acid (AAA) treatment and measured by a Tandetron Accelerator Mass Spectrometry system (AMS, Model-4130, HVEE) at the Center for Chronological Research, Nagoya University. The ${ }^{14} \mathrm{C}$ ages obtained from the total organic carbon in the sediment were older than the plant residues of the same layers, which could be interpreted as carbon reservoir effect [21]. To obtain accurate sediment ages, 25 plant residue samples picked out from Core PY608W were identified. Their ages and organic carbon isotope measurements also were obtained [22]. Since plant residues probably include aquatic plants, which will lead to reservoir effect, ${ }^{210} \mathrm{~Pb}$ radionuclide activities of the top $8 \mathrm{~cm}$ of sediment were measured by well-type high purity germanium gamma spectrometry (ORTEC GWL-120-15) in ITPCAS to further evaluate the reservoir effect. The measurement time for each sample was $8 \times 10^{4} \mathrm{~s}$. 


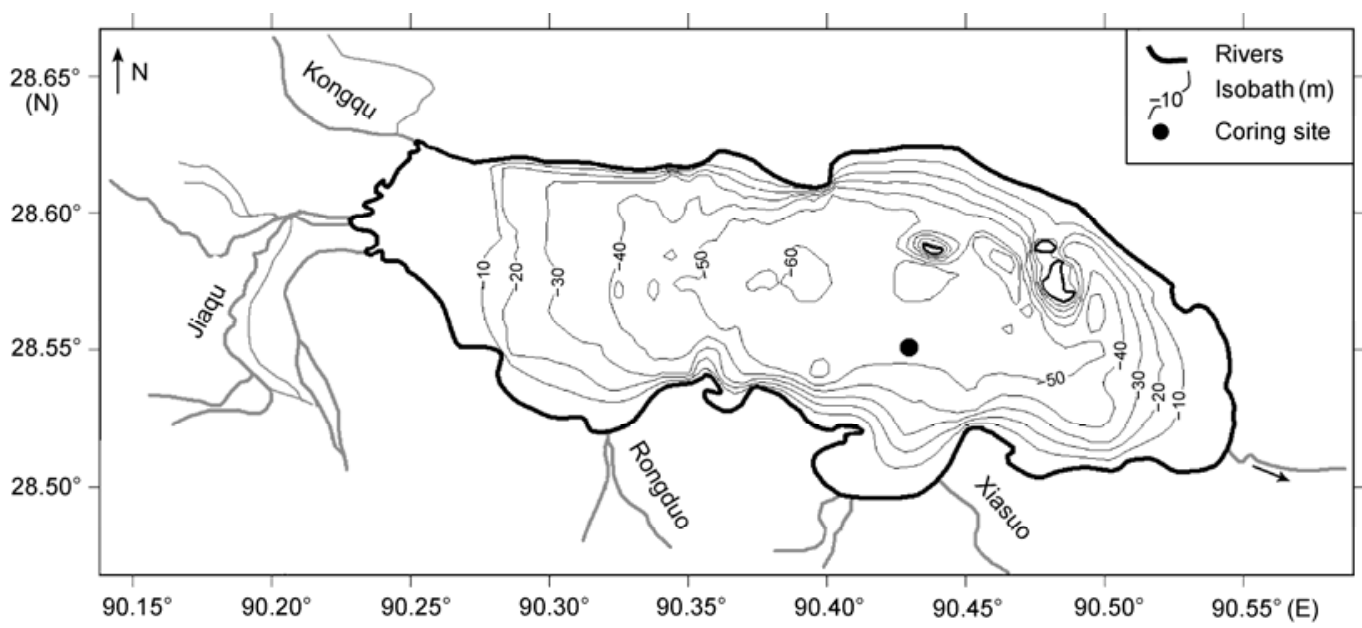

Figure 1 Map of the location of Pumoyum Co and the coring site.

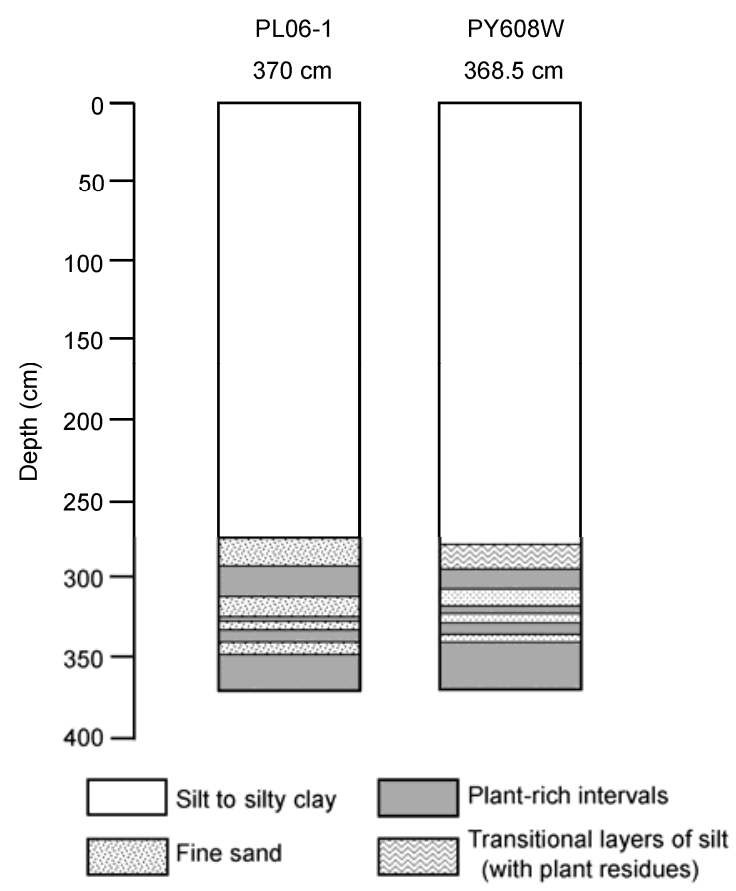

Figure 2 The sedimentary facies of the two cores from Pumoyum Co.

\subsection{Environmental proxies and measurements}

Lake sediment total organic carbon (TOC) reflects inputs and maintenance of autochthonous and allochthonous organic material, and are controlled by aquatic plants and terrestrial plants [23]. TOC content variations have explicit environmental significance if the origin of TOC can be determined. Sediment inorganic carbon (IC) has a significantly positive correlation with carbonate content [24], and the latter represents evaporation in a hydrologically closed lake [25]. TOC and IC were analyzed using a Shimadzu TOC$\mathrm{V}_{\mathrm{CPH}}$ with solid sample module SSM-5000A, utilizing the combustion method at ITPCAS. Sediment grain size is a direct reflection of lake hydrological dynamics, because the land surface environment and changes in replenishment conditions will result in variability of grain size and material components. Grain size was measured with a Malvern Mastersizer 2000 laser diffraction particle size analyzer at the Institute of Geographical Sciences and Natural Resources Research, CAS. The measurements ranged from 2 to $2000 \mu \mathrm{m}$. All TOC, IC and grain size measurements were conducted at core intervals of $1 \mathrm{~cm}$. The pollen assemblage and pollen concentration are important indicators of vegetation and climate evolution. Pollen samples were prepared at $20-\mathrm{cm}$ intervals along the core length with volumes of $7 \mathrm{~cm}^{3}$. These samples were analyzed at Okayama University of Science, Japan [26]. Pollen samples were treated with a modified acetolysis procedure, including $10 \% \mathrm{HCl}, 10 \%$ $\mathrm{KOH}$, acetolysis treatments and $\mathrm{ZnCl}_{2}$ heavy liquid (specific gravity of 1.68). More than 300 pollen grains were counted for each sample. For samples with few pollen grains, all the slides were counted.

\section{Results}

\subsection{Sediment core comparisons and chronology}

Based on the analysis of grain size and plant residue layers of Core PL06-1 and PY608W, AMS ${ }^{14} \mathrm{C}$ ages of the plant residues were measured for both cores. Results showed that the ages of plant residues in the same layer depth in both cores were identical (Table 1). Thus, the ages at the same layer depth of the two cores are essentially interchangeable.

Twenty-five plant residue samples of Core PY608W were singled out to determine sediment ages by the AMS ${ }^{14} \mathrm{C}$ chronological method, and 25 valid age data were obtained (Table 2). According to Watanabe's analysis [21], the content of ${ }^{14} \mathrm{C}$ in submerged plants (Ruppia, Potamogetonaceae, Charophyceae) in the lake is comparable to that of atmosphere, and the content of ${ }^{14} \mathrm{C}$ for terrestrial plants generally is in balance with that of the atmosphere. Thus, 
Table $1{ }^{14} \mathrm{C}$ dating data of lower sections of Core PL06-1 and PY608W in Pumoyum Co

\begin{tabular}{|c|c|c|c|c|c|}
\hline Materials & Depth $(\mathrm{cm})$ & $\delta^{13} \mathrm{C}(\% o)$ & Laboratory code & Calibrated age (cal a BP) & Error $( \pm a)$ \\
\hline \multicolumn{6}{|l|}{ Core PL06-1 } \\
\hline Aquatic plant residues & 303.0 & -8.4 & NUTA2-12105 & 15545 & 183 \\
\hline Aquatic plant residues & 329.0 & -3.7 & NUTA2-12070 & 17931 & 141 \\
\hline Aquatic plant residues & 337.0 & -2.2 & NUTA2-12083 & 17851 & 143 \\
\hline Aquatic plant residues & 347.0 & -5.3 & NUTA2-12071 & 18294 & 196 \\
\hline Aquatic plant residues & 357.0 & -4.0 & NUTA2-12072 & 18599 & 92 \\
\hline Aquatic plant residues & 367.0 & -11.0 & NUTA2-12085 & 18721 & 82 \\
\hline \multicolumn{6}{|l|}{ Core PY608W } \\
\hline Aquatic plant residues & 301.2 & -6.7 & NUTA2-12740 & 15350 & 146 \\
\hline Aquatic plant residues & 327.7 & -8.3 & NUTA2-13976 & 18940 & 46 \\
\hline Aquatic plant residues & 336.2 & -3.9 & NUTA2-12755 & 17939 & 143 \\
\hline Aquatic plant residues & 346.8 & -3.1 & NUTA2-12759 & 18160 & 287 \\
\hline Aquatic plant residues & 368.5 & & NUTA2-12138 & 18684 & 64 \\
\hline
\end{tabular}

Table $2{ }^{14} \mathrm{C}$ and calibrated dating data of Core PY608W (PL06-1) in Pumoyum Co

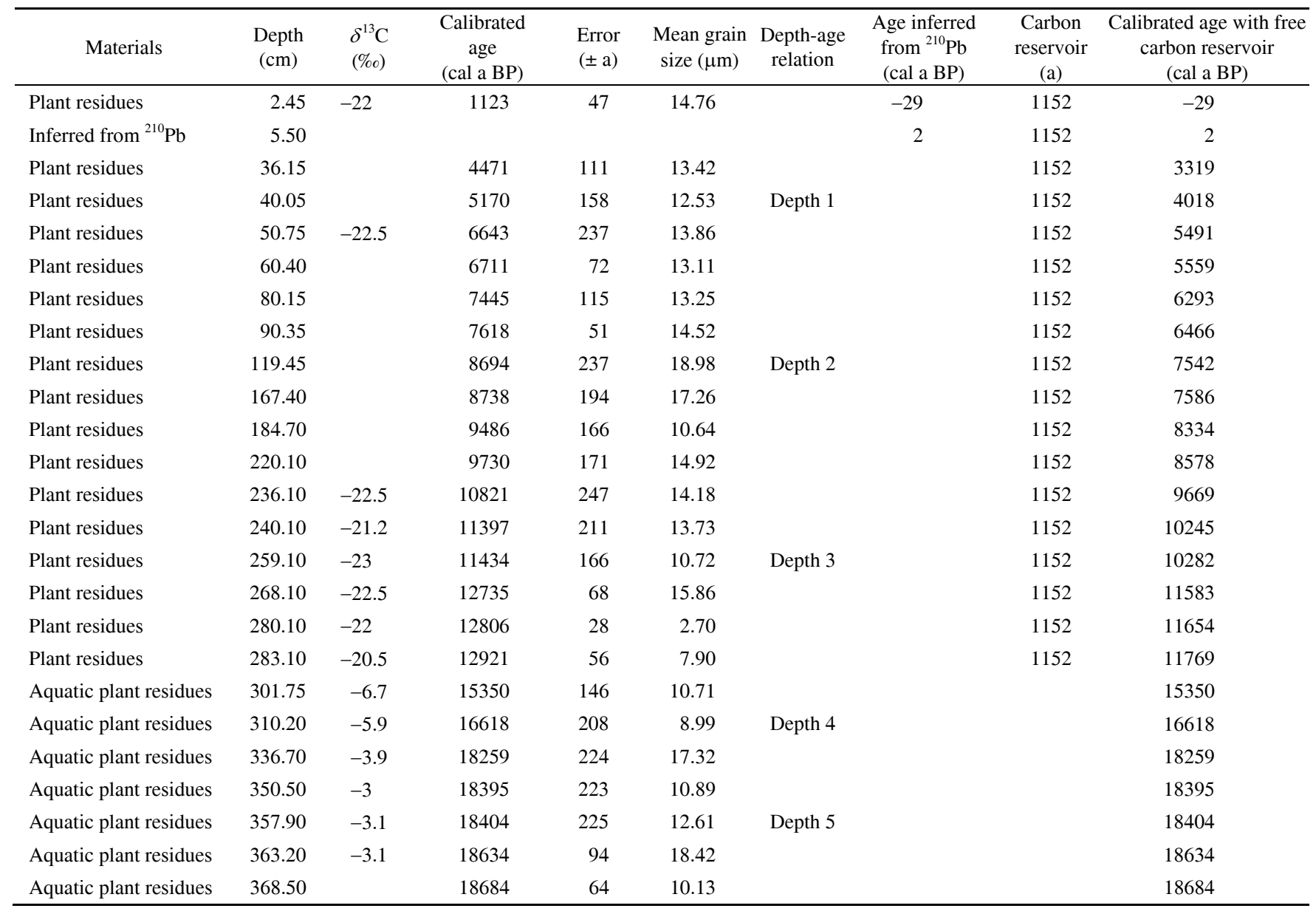

there is no old carbon on dating of these plant residues. However, the ${ }^{14} \mathrm{C}$ contents in the modern Potamogetonaceae and Charophyceae in wetlands around the lake were $80.3 \pm$ 0.5 to $84.8 \pm 0.5 \mathrm{PMC}$ (percent modern carbon). These values were less than those of the atmosphere (108 PMC) [22], suggesting that reservoir effect could exist for ${ }^{14} \mathrm{C}$ age measurements from lake plant residues. The $\delta^{13} \mathrm{C}$ values of upper sediment plant residues $(2.45-283.10 \mathrm{~cm})$ varied from $-23 \%$ o to $-20.5 \%$ o (Table 2), which were greater than the values of terrestrial $\mathrm{C}_{3}$ herbs $(-28.1 \%$ o to $-23.9 \%$ ) 
around the lake [22]. Conversely, submerged plants including Potamogetonaceae and Charophyceae exhibit $\delta^{13} \mathrm{C}$ values of $-15.2 \%$ o to $-11.5 \%$ o. Consequently, such plant residues should be mixtures of terrestrial $\mathrm{C}_{3}$ herbs and aquatic plants, and reservoir effect possibly exists. The $\delta^{13} \mathrm{C}$ values of lower sediment plant residues $(301.75-363.20 \mathrm{~cm})$ were $-10.8 \%$ o to $-3 \%$ o, which were very close to those of shallow aquatic plants, such as Ruppia (-6.7\%o to $-4.7 \%$ ) [27]. Since the ${ }^{14} \mathrm{C}$ content of modern Ruppia (108 PMC) is in agreement with that of the atmosphere, the carbon reservoir effect can be neglected for plant residues in the lower sediment.

The upper sediment ${ }^{210} \mathrm{~Pb}$ rates of Core PL06-1 were determined, and sediment rates and ages were calculated for the top $8 \mathrm{~cm}$ using the CRS model (Table 3). The sediment age at a depth of $2.5 \mathrm{~cm}$ was $-29 \mathrm{cal}$ a BP (AD 1979) and its calibrated ${ }^{14} \mathrm{C}$ age was 1123 a BP. Thus, the carbon reservoir effect of the upper sediment $(0-283 \mathrm{~cm})$ is $1152 \mathrm{a}$, assuming homogeneous reservoir effect for upper sediment plant residues (Table 3). Based on character analysis of sediment grain size and plant residues used for dating, age models for the entire sediment core were established at five different zones to calculate absolute sediment ages (Figure 3).

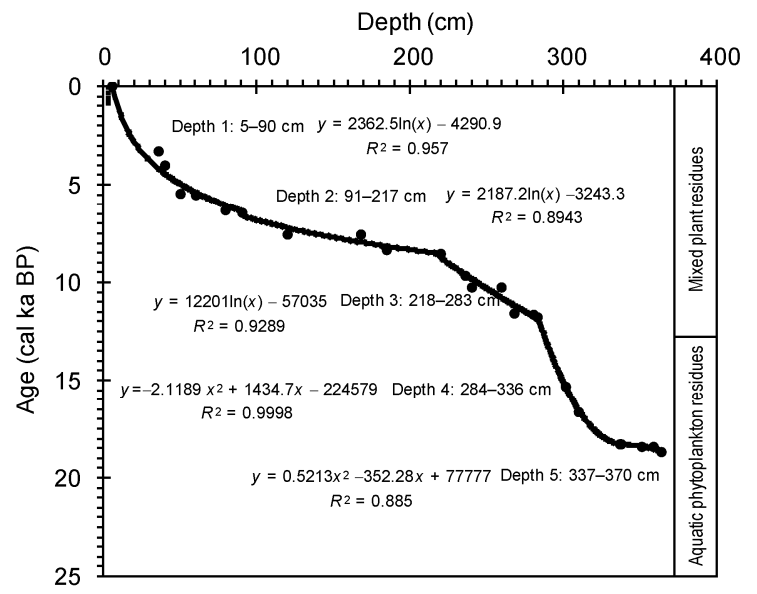

Figure 3 Correlations between calibrated dating data and depths of Core PY608W (PL06-1) in Pumoyum Co.

\subsection{Proxy analysis}

Based on the age-depth model of Core PL06-1, variations of TOC, IC and grain sizes since 19 cal ka BP are shown in Figure 4. Content of TOC and IC fluctuated dramatically prior to $11.8 \mathrm{cal} \mathrm{ka}$ BP. TOC and IC had almost opposite variations before $17.2 \mathrm{cal} \mathrm{ka} \mathrm{BP}$. TOC reached peak values during 18.8-18.2 cal ka BP and 17.6-17.2 cal ka BP, while IC represented valley values at those times. TOC valley values and IC peak values occurred during 18.2-17.6 cal ka BP. During 16.2-15.6 cal ka BP, both TOC and IC had valley values. IC dropped dramatically to nearly 0 , while TOC stabilized at $1 \%$ between 15.6 and 13.2 cal ka BP. From 13.2 to 11.8 cal ka BP, TOC maintained a relatively high level, and then decreased gradually from 11.8 to $8.2 \mathrm{cal} \mathrm{ka}$ BP. Conversely, IC remained at zero during the same times. At 8.2 cal ka BP, TOC had lower values and then increased gradually along with IC.

Sediment grain size transitions occurred at about $11.8 \mathrm{cal}$ ka BP (Figure 4). The mean grain size $\left(M_{\mathrm{z}}\right)$ was dominated by coarser grain sizes before $11.8 \mathrm{cal} \mathrm{ka} \mathrm{BP}$, and were finer after that. $M_{\mathrm{z}}$ was controlled by the content of coarse grains $(>63 \mu \mathrm{m})$. The content of coarse grain size $(>63 \mu \mathrm{m})$ was similar to that of TOC before $17.2 \mathrm{cal} \mathrm{ka}$ BP. During 17.211.8 cal ka BP, fine grain sizes $(<4 \mu \mathrm{m})$ were synchronous with TOC, whereas after 11.8 cal ka BP, neither $M_{\mathrm{z}}$ nor different grain size classes varied greatly, indicating no relationship with TOC fluctuation.

A total of 32 pollen taxa were recognized from the fossil pollen record in Core PL06-1. Pollen from tree and shrub taxa included Pinus, Abies, Picea, Tsuga, Juglans, Betula, Alnus, Carpinus, Corylus, Quercus, Cyclobalanopsis, Castanea, Ulmus/Zelkova and Camellia. Meadow pollen taxa were composed of Ericaceae, Cyperaceae, Caryophyllaceae, Bistorta, Lagerstroemia, Typha and Thalictrum. Steppe pollen taxa included Gramineae, Cruciferae, Rosaceae, Leguminosae, Umbelliferae, Compositae and Artemisia. Desert pollen taxa consist of Chenopodiaceae/Amaranthaceae, Ephedra, Hippophae and Tamarix.

Pollen concentrations and assemblages are summarized

Table 3 Extra ${ }^{210} \mathrm{~Pb}$ of upper sediment of Core PL06-1 in Pumoyum Co and their absolute ages

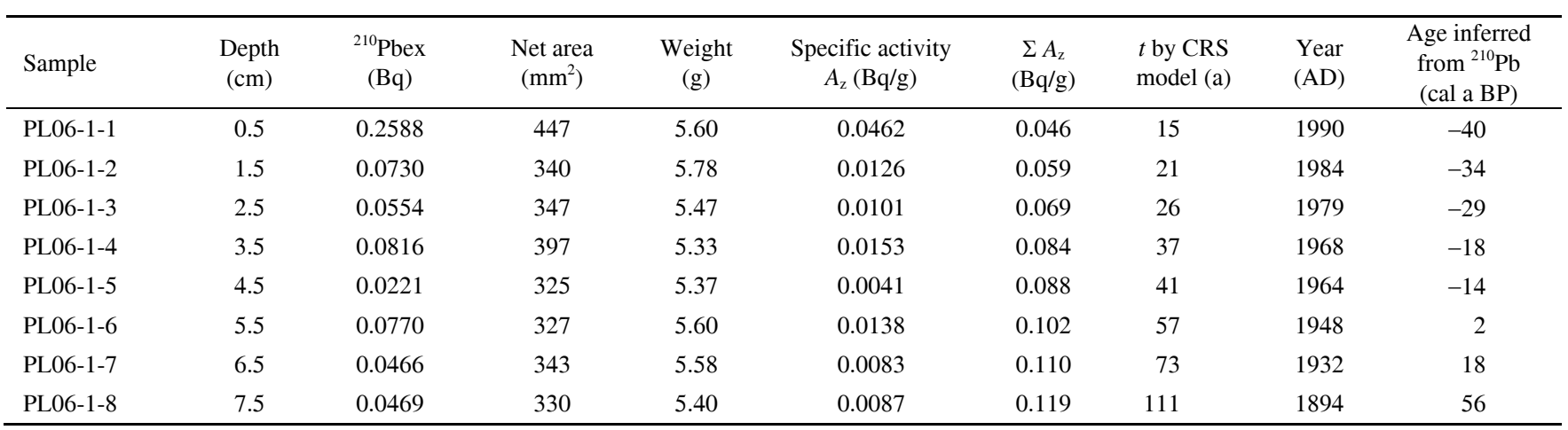




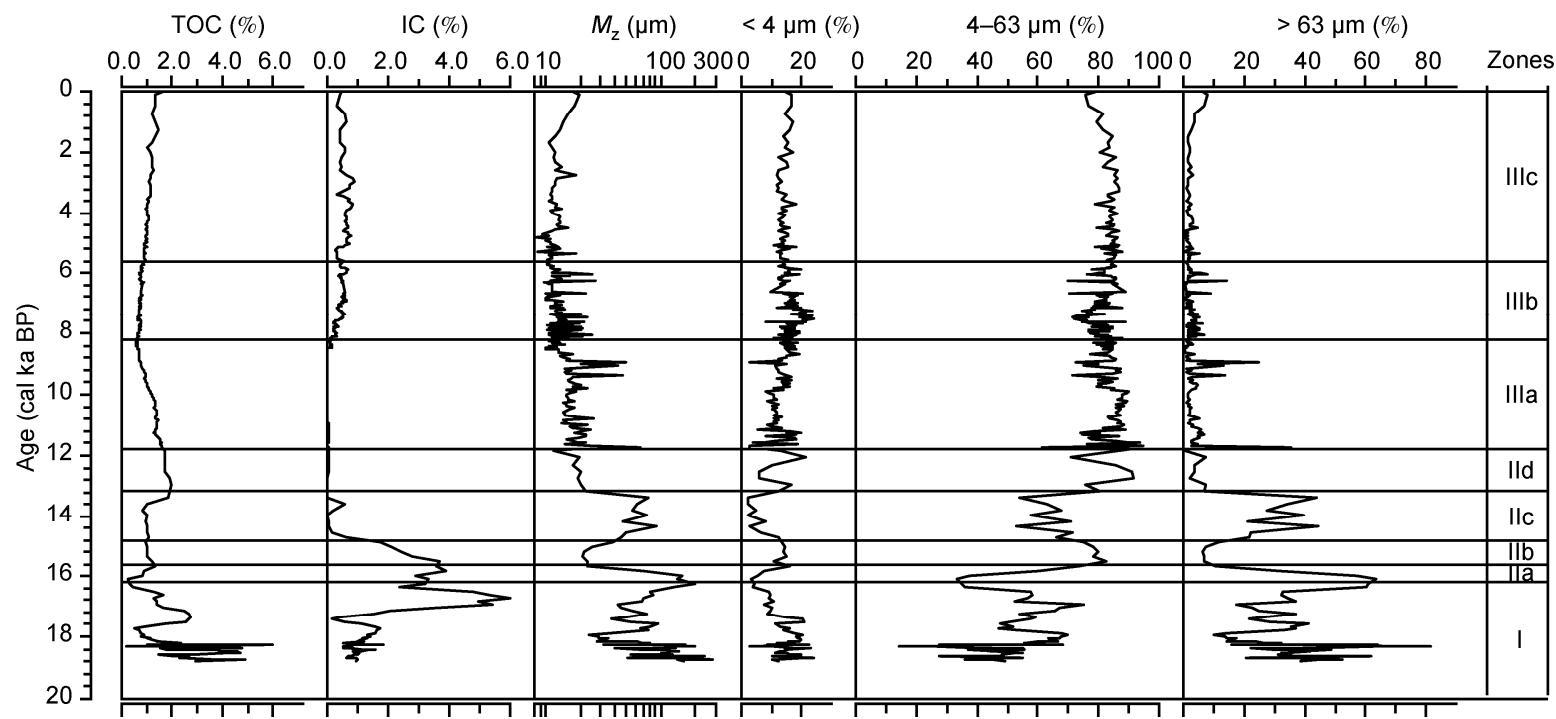

Figure 4 Variations of TOC, IC and grain sizes of Core PL06-1 in Pumoyum Co since 19 cal ka BP.

in Figure 5. Overall, pollen concentrations were less than 100 grains $/ \mathrm{cm}^{3}$, suggesting poor conditions for vegetation development around the lake. Because of the low pollen amounts, pollen assemblages which reflected different thermal and moisture conditions were used to reconstruct the past climate and environmental evolution. Before 14.8 cal ka BP, the variation of pollen concentrations coincided with meadow and steppe pollen assemblages. At higher pollen concentration of $19.4 \mathrm{cal} \mathrm{ka} \mathrm{BP}$ and $16.5 \mathrm{cal} \mathrm{ka} \mathrm{BP}$, tree and shrub pollen percents were relatively low, indicating that pollen concentrations during this period were mainly controlled by herbs. From 14.8 to 11.8 cal ka BP, pollen concentration varied with meadow and desert pollen, especially desert, indicating that pollen content was influenced by both wetland vegetation around the lake and arid conditions. High arboreal pollen and lower pollen concentration at $14.2 \mathrm{cal} \mathrm{ka}$ BP indicated that the pollen spectrum was affected by regional arboreal taxa. Between 11.8 and $8.2 \mathrm{cal}$ ka BP, pollen concentration varied with arboreal and desert pollen, unlike steppe pollen, suggesting that arid vegetation developed around the lake and more regional arboreal vegetation. During 8.2-5.6 cal ka BP, pollen concentrations were in agreement with arboreal and steppe pollen, while the trend was the opposite with desert pollen. This suggests that proper thermal and moisture conditions in this period favored arboreal and steppe environments, and limited desert vegetation. After 5.6 cal ka BP, pollen concentrations gradually increased at very low levels. This also was the case for arboreal and desert pollen, unlike steppe and meadow pollen, which reflected a dry climate around the lake.

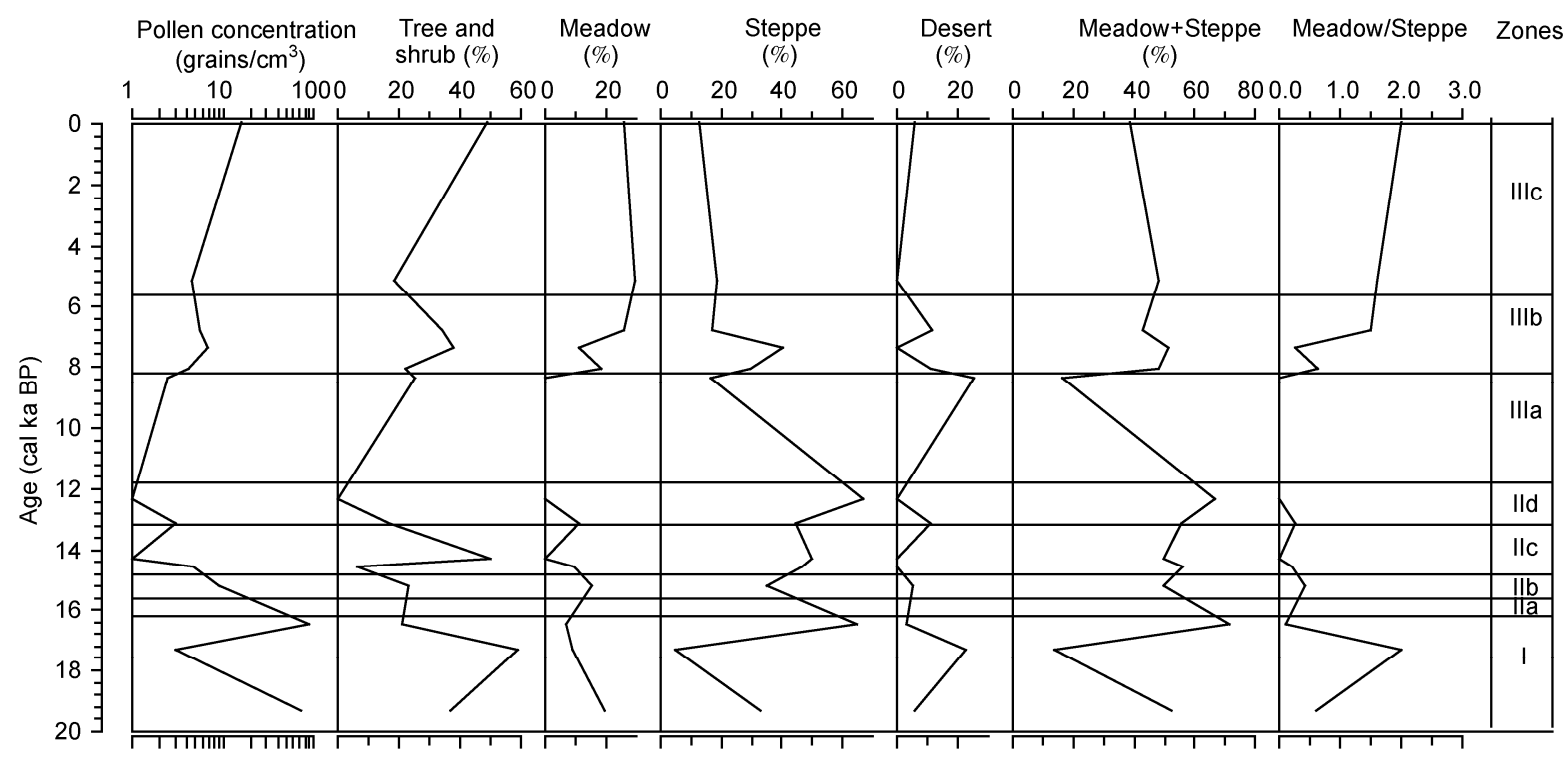

Figure 5 Variations of pollen assemblages of Core PL06-1 in Pumoyum Co since 19 cal ka BP. 


\section{Discussion}

\subsection{Lake development and expansion during deglaciation (19-16.2 cal ka BP)}

Generally, lower levels of lake water were influenced by surface waves or rivers flowing into the lake, and strong hydrological forces. According to the vertical distribution of water temperature in Pumoyum Co [28], wave base in the lake was less than $20 \mathrm{~m}$. Sediments found at depths greater than $20 \mathrm{~m}$ were dominated by silt-clay $(<63 \mu \mathrm{m})$ [29] and were less influenced by lake wave re-sedimentation. Thus, fine sands and extremely fine sands $(>63 \mu \mathrm{m})$ mainly were distributed in shallow water environments. The mean grain sizes in Core PL06-1 prior to 15.6 cal ka BP were more than $63 \mu \mathrm{m}$, and those of coarse grain sizes $(>63 \mu \mathrm{m})$ exceeded $40 \%$, indicating a shallow lake during this period. However, TOC inversely changed with IC only before 17.2 cal ka BP and confirmed the change in grain size. Since plant residuerich layers occurred in this part of the sedimentary section, higher TOC was connected with aquatic plant development and their fragmental inputs. Since the IC content in sediment is highly coupled with $\mathrm{CaCO}_{3}$, more IC demonstrated a shallow lake environment. This shallow component readily evaporates, and results in IC enrichment. Conversely, IC varied inversely with grain size, indicating input of glacial meltwater with low carbonate content to the lake [23], which possibly weakened the enrichment of sediment IC. Based on the above analysis, we suggest that glacial melting started at the beginning of the deglaciation and favored the gradual expansion of the lake, although the meltwater was not plentiful at that time.

Pollen concentrations were not high, and were dominated by arboreal and desert vegetation. Since no arboreal plants are found in the Pomuyum Co basin at present [30], the arboreal pollen may have been transported by wind from a long distance away. Pollen concentrations from higher desert plants during this period may indicate an arid climate. Aquatic plant residues in the core sediment layers were conserved in-situ. In light of the survey of Pumuyum Co, the modern aquatic plants appear to survive at a maximum underwater depth of $15 \mathrm{~m}$, owing to the high water clarity of the area [30]. Thus the fossilized in-situ conserved aquatic plants layers mirrored shallow water level environments, and greater amounts of desert pollen reflected a small lake area and very low moisture around the lake.

\subsection{Environmental fluctuation and abrupt change during post glacial times (16.2-11.8 cal ka BP)}

Based on the variation of TOC, IC, mean sediment grain size and pollen concentrations after $16.2 \mathrm{cal}$ ka BP, different stages in lake development may be discussed as follows. Mean grain size content greatly decreased during the period of 16.2 to $15.6 \mathrm{cal} \mathrm{ka} \mathrm{BP}$ and 13.2 to $11.8 \mathrm{cal} \mathrm{ka} \mathrm{BP}$, and it increased and maintained higher values during 15.6 to 14.8 cal ka BP and 14.8 to 13.2 cal ka BP, respectively. The content of TOC rose gradually between 16.2 and $15.6 \mathrm{cal} \mathrm{ka}$ $\mathrm{BP}$, then stabilized from 15.6 to $13.2 \mathrm{cal} \mathrm{ka} \mathrm{BP}$, and then retained higher values from 13.2 to $11.8 \mathrm{cal} \mathrm{ka} B P$. IC values increased gradually from 16.2 to $15.6 \mathrm{cal} \mathrm{ka} \mathrm{BP}$, and dropped sharply during 15.6-14.8 cal ka BP. IC values were consistently low during the period of $14.8-11.8$ cal ka BP. Pollen concentrations have declined since 16.2 cal ka BP, and reached low values at 14.2 and $11.8 \mathrm{cal}$ ka BP. However, meadow, steppe and desert pollen assemblages have been relatively stable while the lake conditions varied greatly during this period.

The mean sediment grain size was low and decreased greatly from 16.2 to $15.6 \mathrm{cal} \mathrm{ka} \mathrm{BP}$, indicating that continuous water supplements increased the lake level. Conversely, the rising IC content indicates that lake evaporation continued to provoke calcium carbonate precipitation. During the period of $15.6-14.8$ cal ka BP, the mean grain size sharply increased, yet IC values dropped dramatically. There was no significant change in TOC, suggesting that increasing glacial meltwater led to the increase in sediment grain size and dilution of calcium carbonate deposition. From 16.2 to 14.8 cal ka BP, pollen concentrations continued to decline, as did arboreal pollen. This shift indicates that the abatement of winds resulted in less exotic arboreal pollen. However, more meadow pollen and less desert pollen during this period suggest more moisture around the lake. For lakes with water input dominated by glacial meltwater, the increase of lake levels and the enhancement of evaporation reflect warm conditions. From 14.8 to $13.2 \mathrm{cal}$ ka BP, mean grain sizes maintained relatively higher values. Generally, pollen concentrations abruptly declined as did meadow pollen assemblages, while arboreal pollen increased dramatically. These changes possibly reflect a weak cold environmental event. In other words, local meadow pollen concentrations decreased and exotic arboreal pollen concentrations increased because of a cold and dry climate shift. In addition, less glacial meltwater led to lower lake levels. During 13.2-11.8 cal ka BP, the mean grain size declined again and IC maintained very low levels. This demonstrates weak hydrological forces and weak evaporation. The values of pollen concentration, arboreal, meadow and desert pollen were very low, except for steppe pollen, indicating poor vegetation conditions. However, higher values of TOC probably were linked to increasing pollen content at 13.2 cal $\mathrm{ka} \mathrm{BP}$, as well as an increase in the number of aquatic organisms.

\subsection{Deep water levels and climate change during the Holocene (11.8 cal ka BP to present)}

After 11.8 cal ka BP, sediment grain size was stable and dominated by silt-clay, demonstrating that water depth of the coring site was beyond the depth of surface wave 
influence. From 11.8 to 8.2 cal ka BP, TOC decreased steadily and IC was maintained at nearly zero. TOC and IC gradually increased after TOC reached its lowest level at about 8.2 cal ka BP. Pollen concentrations generally increased after 11.8 cal $\mathrm{ka} \mathrm{BP}$, showing a parallel variation with arboreal pollen. However, during 11.8-8.2 cal ka BP, steppe pollen declined dramatically, while desert pollen increased markedly. Although there is a lack of high resolution pollen analysis at present to fully evaluate the early Holocene vegetation evolution, we suggest that conditions for aquatic plants were not suitable during that time because of deeper lake levels. Moreover, from 11.8 to $8.8 \mathrm{cal} \mathrm{ka} \mathrm{BP}$, sediment $\mathrm{Mz}$ reached peak values during the Holocene, while clay $(<4 \mu \mathrm{m})$ was relatively minor. More silt grains or coarse grains could have brought more terrestrial organic matter into the lake. Thus, the environment in the early Holocene favored terrestrial plant development, and maintained high input of terrestrial organic material. The lower TOC values, minor steppe pollen concentrations and more desert pollen at 8.2 cal ka BP reflect dry climate conditions, suggesting an abrupt environmental event, but there is no indication of aridity in the lake area from the early to middle Holocene.

Between 8.2 and $5.6 \mathrm{cal}$ ka BP, pollen concentrations and arboreal pollen content continued to rise. Meadow pollen concentrations also increased sharply, while desert pollen concentrations dropped dramatically, indicating a warm and moist climate, which favored meadow development around the lakeshore. The increased arboreal pollen content could have resulted from enhanced vegetation conditions within the basin or pollen source area expansion. At $7.2 \mathrm{cal} \mathrm{ka}$ BP, pollen concentration, arboreal pollen and steppe pollen assemblages reached their peaks, suggesting better vegetation conditions in the middle Holocene. After 5.6 cal ka BP, although pollen concentrations still increased, meadow and steppe pollen contents declined and arboreal and desert pollen contents increased, reflecting dry climate conditions.

\subsection{Comparison with other lakes records in southern Tibet}

Although lake sediment research has been conducted in the Tibetan Plateau previously, there are few studies which include continuous records covering long-term intervals over the last deglaciation. High-resolution lake sediment records have been obtained from Yidun Lake [6] in southern Tibet and Ren Co [7] in the southeastern Plateau, Yanmdrok Lake [13] in the southern Plateau, and Peiku Co [8] and Zabuye Lake [12] in the southwestern Plateau. Moreover, the recent environmental records of Naleng Lake [31] in the eastern Plateau and Ximen Co [32] are dominated by glacial meltwater supplies, and could be compared with our results, even though both lakes experience the influence of the southeast monsoon. For comparison, all ages were converted from AMS ${ }^{14} \mathrm{C}$ ages to calendar ages.
Before 16.2 cal ka BP, cold and dry steppe landscapes dominated Yidun Lake, and desert landscapes dominated in Ren Co. Large-sized glaciers in Ximen Co and increasing glacier meltwater may have brought coarse and weathered material with higher magnetic susceptibility. The vegetation of Naleng Lake may have shifted from steppe to meadow. The moisture in Yanmdrok Lake may have gradually increased, while the temperature may have still remained relatively low. Chemical proxies in Zabuye Lake indicated frozen conditions. During this period, continuously increasing glacier meltwater may have led to Pumoyum Co expansion. In addition, more exotic arboreal pollen and desert pollen indicated increasing temperatures and relatively low moisture. For the spatial differentiation of environmental changes, relatively cold and dry conditions in the southeastern and the southern Plateau suffered more from large-scale glaciers at the beginning of deglaciation, and the variation of moisture was determined by glacial meltwater.

From 16.2 to 11.8 cal ka BP, sub-alpine meadows developed in the Yidun Lake area and temperatures rose, except for a short decline at $11 \mathrm{cal} \mathrm{ka}$ BP. Vegetation in Ren Co shifted from desert steppes to meadow steppes. Coarser sediment grain sizes in Ximen Co during the 16.5-14.5 cal ka BP interval indicate more glacial meltwater. From 14.5 to 10.4 cal ka BP, less weathering material with higher magnetic susceptibility values and fine grain size indicate a greater distance between glaciers and lakes. At $10.6 \mathrm{cal} \mathrm{ka}$ BP, TOC values markedly declined with increase in coarser grain sizes. The Naleng Lake area was dominated by alpine meadows during the 14.8-10.7 cal ka BP interval. Higher moisture and lower temperatures in Yanmdrok Lake from 16.5 to $10.5 \mathrm{cal} \mathrm{ka}$ BP may have existed, including a distinct cold event at $14.5 \mathrm{cal} \mathrm{ka} \mathrm{BP}$. The decrease of $\mathrm{CaCO}_{3}$ content and coarser grain size in Zabuye Lake indicate warm and moist conditions due to more glacial meltwater, except for an extreme cold and dry event at about 10.5 cal ka BP. In this period, Pumoyum Co frequently varied, and more glacial meltwater at the early stage of the $16.2-14.8 \mathrm{cal} \mathrm{ka}$ $\mathrm{BP}$ interval resulted in warm and moist conditions. Two cold events occurred at 14.2 and 11.8 cal ka BP during the later stage of the 14.8-11.8 cal ka BP interval. Overall, relatively warm and moist conditions were prevalent across the entire southern Tibet regions from deglacial to post glacial periods. Moreover, cold events were recorded in lake sediments of different lakes. Although there are differences in dating material and carbon reservoir effects among them, cold events occurred in Pumoyum Co and Ximen Co during 14.5-14.2 cal ka BP and 11.8-10.6 cal ka BP, respectively. This indicates that lakes recharged mainly by glacier meltwater probably recorded more cold events and were more sensitive to variations in glacial meltwater due to temperature changes.

Vegetation in Yidun Lake shifted from meadow to forest at $10.5-8.2$ cal $\mathrm{ka} \mathrm{BP}$, and the reconstructed maximum precipitation and relatively higher temperatures occurred 
during 8.2-5.8 cal ka BP. In addition, the reconstructed temperature and precipitation declined from 5.8 to $1.5 \mathrm{cal} \mathrm{ka}$ $\mathrm{BP}$, and Ren Co may have become drier after 4 cal ka BP. Between 10.4 and 3.6 cal ka BP, sediment TOC contents in Ximen Co maintained higher values, and relatively smaller amounts of weathering material with higher magnetic susceptibility may have been delivered by glacial meltwater. This indicates glaciers far away from the lake as well as warm conditions with higher productivity around the lake. After $3.6 \mathrm{cal}$ ka BP, coarser sediment grain sizes and more weathering material of high magnetic susceptibility suggest relatively bare land surfaces. Alpine meadows expanded around Naleng Lake, indicating warmer and moister conditions. The climate in Yanmdrok Lake shifted from warm to cold and moist to dry during 10.5-9 cal ka BP, and then became warm, followed by cold conditions again during 9-6 cal ka BP. The optimum conditions occurred at about 6 cal ka BP, and then warmer and dryer conditions followed, with a significant dry event at 5.5-5 cal ka BP. A wet pulse occurred in Peiku Co at about 14.7 cal ka BP and a cooling phase occurred at about 12.8 cal ka BP, contemporaneous with the YD event. Dry climate was prevalent at $11.4 \mathrm{cal} \mathrm{ka}$ BP, and lasted until 7.7 cal ka BP. Zabuye Lake was optimally warm from 9.5 to 5.8 cal ka BP, except for a cold event at $7.8 \mathrm{cal} \mathrm{ka} \mathrm{BP}$, and the climate was dry after $5.8 \mathrm{cal}$ ka BP. The environmental change in Pumoyum Co indicates a basically consistent pattern with other lakes in southern Tibet. Furthermore, the optimum middle Holocene interval only occurred between 8.2-5.6 cal ka BP, especially at about 7.2 cal ka BP, resulting from increasing glacial meltwater replenishment.

\section{Conclusions}

Although AMS ${ }^{14} \mathrm{C}$ dating based on plant residues in lake sediment can greatly allieviate carbon reservoir effect, further age calibration could be made by surface sedimentation rate measurements to minimize reservoir effect in sediment mixtures. Modern submerged plants of Ruppia, Potamogetonaceae and Charophyceae in Pumoyum Co had similar contents of ${ }^{14} \mathrm{C}$ compared to those of the atmosphere, indicating a balance of $\mathrm{CO}_{2}$ between lake water and atmosphere. However, Potamogetonaceae and Charophyceae that grew in swamps around lakeshores could utilize sluggish surface water or underground water to absorb more old carbon material, resulting in the content of ${ }^{14} \mathrm{C}$ in submerged plants around lakeshores being less than that of the atmosphere. Thus, AMS ${ }^{14} \mathrm{C}$ dating of sediment plant residues may retain reservoir effect if the ecology and origins of terrestrial or aquatic plants could not be accurately determined. However, this carbon reservoir effect could be stable under the conditions of similar ratios of terrestrial/aquatic plants components, and be considered as the difference in ages between surface sedimentation rate measurements and plant residue dating in the sediment records.

The evolutionary history of Pumoyum Co demonstrates that for lakes mainly recharged by glacial meltwater, lake expansion is correlated with climate change. Modern $\mathrm{Pu}-$ moyum Co development may be a result of continuous glacial meltwater supplied since the last deglaciation. Before 16.2 cal ka BP, Pumoyum Co was a shallow lake. From 16.2 to 11.8 cal ka BP, lake level increased and the sedimentary environment fluctuated dramatically and frequently. Two cold events at 14.2 and 11.8 cal ka BP may be compared to the Old Dryas and the Younger Dryas, respectively. Since $11.8 \mathrm{cal} \mathrm{ka}$ BP, sedimentation has been located in the deep water environment, typified by weak hydrological forces and only minor grain size variation. While the temperature of lake water was lower because of glacial meltwater coming into the lake, environment proxies were not sensitive to warm conditions only reflected by indicators from terrestrial vegetation.

From the available lake sediment records in southern Tibet, it can be said that the warm climate at the beginning of the last deglaciation greatly influenced the southeastern Plateau, while the influence gradually became weaker in the southern and the southwestern plateau. The possible reason for this could be that the southwest monsoon could have strengthened since the last delagical, and gradually expanded to the inner plateau. The cold events during the deglacial peroid can be reflected in all lake records to different extents by different indicators. Lakes supplied mainly by glacial meltwater were more sensitive to cold events. The early warm and moist climate, the middle optimum period, and the cold and dry interval later in the Holocene are all recorded in the lakes of the southern Tibet region, suggesting a strong influence by the southwest monsoon.

Special thanks are extended to the China-Japan Scientific Research Expedition to Pumoyum Co on the Tibetan Plateau, for their help during the acquisition of the sediment core samples. We also thank two anonymous reviewers for their valuable comments that helped to improve our manuscript. This work was supported by the National Natural Science Foundation of China (40871099 and 40810166), the Knowledge Innovation Key Program of the Chinese Academy of Sciences (KZCX2-YW-146 and KZCX2-EW-113), and the Special Pilot Research of the Chinese Academy of Sciences (XDA05120301).

1 PAGES. Science Plan and Implementation Strategy. IGBP Report No. 57. Stockholm: IGBP Secretariat, 2009. 67

2 Brown A G. Learning from the past: Palaeohydrology and palaeoecology. Freshw Biol, 2002, 47: 817-829

3 Schefuß E, Schouten H, Schneider R R. Climatic controls on central African hydrology during the past 20000 years. Nature, 2005, 437: 1003-1006

4 Zheng D. The system of physico-geographical regions of the QinghaiXizang (Tibet) Plateau. Sci China Ser D-Earth Sci, 1996, 39: 410417

5 Jarvis D I. Pollen evidence of changing Holocene monsoon climate in Sichuan Province, China. Quat Res, 1993, 39: 325-337

6 Shen C M, Liu K B, Tang L Y, et al. Quantitative relationships between modern pollen rain and climate in the Tibetan Plateau. Rev Palaeobot Palynology, 2006, 140: 61-77 
7 Tang L Y, Shen C M, Liu K B, et al. Climatic and hydrological changes in the southeastern Qinghai-Tibetan Plateau during the past 18000 years. Acta Micropalaeontol Sin, 2000, 17: 113-124

8 Huang F. Vegetation and climate between 13 to $5 \mathrm{ka}$ BP in Peiku, Tibet (in Chinese). Acta Micropalaeontol Sin, 2000, 39: 441-448

9 Zhu L P, Wu Y H, Wang J B, et al. Environmental changes reflected from the core sediments since $8.4 \mathrm{ka}$ in Nam Co, central Tibet of China. Holocene, 2008, 18: 831-839

10 Yang B, Tang L Y, Li C H, et al. An ice-core record of vegetation and climate changes in the central Tibetan Plateau during the last 550 years. Chinese Sci Bull, 2010, 55: 1169-1177

11 Gasse F, Fontes J C, van Campo E, et al. Holocene environmental changes in Bangong Co basin (Western Tibet). Part 4: Discussion and conclusions. Palaeogeogr Paleoclimatol Paleoecol, 1996, 120: 79-92

12 Wang R L, Scarpitta S C, Zhang S C, et al. Later Pleistocene/Holocene climate conditions of Qinghai-Xizhang Plateau (Tibet) based on carbon and oxygen stable isotopes of Zabuye Lake sediments. Earth Planet Sci Lett, 2002, 203: 461-477

13 Zhu L P, Zhen X L, Wang J B, et al. A 30000-year record of environmental changes inferred from Lake Chen Co, Southern Tibet. J Paleolimn, 2009, 42: 343-358

14 Wang S M, Dou H S. China Lake (in Chinese). Beijing: Science Press, 1998. 405

15 Wen S X, Zhang B G, Wang Y G, et al. Strata of Tibet (in Chinese). Beijing: Science Press, 1984. 340-365

16 Li B Y, Wang F B, Zhang Q S, et al. Quaternary Geology in Tibet (in Chinese). Beijing: Science Press, 1983. 15

17 Water Resources Survey and Hydrology Bureau of Tibet. China Hydrological Year Book 1974-1995, Vol. 9. No.1: Yamdrok Lake Basin Hydrologic Data (in Chinese), 1996

18 Zhu L P, Ju J T, Wang J B, et al. Environmental changes recorded in core sediments from the Pumoyum Co lake of the Tibetan Plateau during the initial stage of the last deglacial period (in Chinese). Quat Sci, 2006, 26: 772-780

19 Minami M, Tezuka T, Zhu L P, et al. Preliminary survey of vascular flora around the Lake Pumayum Co, an alpine lake on the southeastern Tibetan Plateau in China. In: Report on the Japan-China scientific research expedition to Lake Pumoyum Co on the Tibetan Plateau (In Japanese), 2006. 39-62

20 Wang J B, Zhu L P, Nishimura M, et al. Spatial variability and correlation of environmental proxies between multiple cores during the past 18000 years in Lake Pumoyum Co, Tibet, China. J Paleolimn,
2009, 42: 303-315

21 Watanabe T, Matsunaka T, Nakamura T, et al. Last-glacial-Holocene geochronology of sediment cores from a high-altitude Tibetan lake based on AMS ${ }^{14} \mathrm{C}$ dating of plant fossils: Implications for paleoenvironmental reconstructions. Chem Geol, 2010, 277: 21-29

22 Watanabe T, Matsunaka T, Nakamura T, et al. A new ${ }^{14} \mathrm{C}$ data set of the PY608W-PC sediment core from Lake Pumoyum Co (Southeastern Tibetan Plateau) over the last 19 kyr. Radiocarbon, 2010, 52: 1435-1442

23 Ju J T, Zhu L P, Wang J B, et al. Water chemistry and sediment characteristics in Lake Pumayum Co, South Tibet, China: Implications for lacustrine carbonate deposition. J Paleolimn, 2010, 43: 463474

24 Krishnamurthy R V, Bhattacharya S K, Sheela K. Palaeoclimatic changes deduced from ${ }^{13} \mathrm{C} /{ }^{12} \mathrm{C}$ and $\mathrm{C} / \mathrm{N}$ ratios of Karewa lake sediments, India. Nature, 1986, 323: 150-152

25 Morrill C, Overpeck J T, Cole J E, et al. Holocene variations in the Asian monsoon inferred from the geochemistry of lake sediments in central Tibet. Quat Res, 2006, 65: 232-243

26 Morita Y. Pollen analysis of the sediments from Lake Pumoyum Co, Tibet. In: Report on the Japan-China Scientific Research Expedition to Lake Pumoyum Co on the Tibetan Plateau (In Japanese), 2006. 63- 66

27 Wang W H, Ji M. Ecological characteristics of submerged macrophyte Ruppiamaritima and its response to environmental changes (in Chinese). Chin Bull Bot, 2006, 23: 98-107

28 Murakami T, Terai H, Yoshiyama Y, et al. The second investigation of Lake Puma Yum Co located in the Southern Tibetan Plateau, China. Limnology, 2007, 8: 331-335

29 Zhu L P, Ju J T, Wang J B, et al. Further discussion about the features of Lake Puma Yum Co, South Tibet, China. Limnology, 2010, 11: 281-287

30 Minami M, Tezuka T, Zhu L P, et al. Survey of vascular flora around Lake Pumayum Co, an alpine lake located in the southeastern Tibetan Plateau in China. J Phytogeogr Taxon, 2010, 58: 50-56

31 Kramer A, Herzschuh U, Mischke S, et al. Late glacial vegetation and climate oscillations on the southeastern Tibetan Plateau inferred from the Lake Naleng pollen profile. Quat Res, 2010, 73: 324-325

32 Zhang C, Mischke S. A Lateglacial and Holocene lake record from Nianbaoyeze Mountains and inferences of lake, glacial and climate evolution on the eastern Tibetan Plateau. Quat Sci Rev, 2009, 28: 1970-1983

Open Access This article is distributed under the terms of the Creative Commons Attribution License which permits any use, distribution, and reproduction in any medium, provided the original author(s) and source are credited. 